Netra Pal Singh ${ }^{1}$

Pankaj Mishra ${ }^{2}$

Ayesha Farooq ${ }^{3}$
JEL: M31, L9

DOI:10.5937/industrija48-26035

UDC: 659.27

659.113.25:621.391

Original Scientific Paper

\title{
An assessment of user's awareness about Indian telecom industry and their assessment of affordability of telecom services in India
}

\author{
Article history: \\ Received: 23 July 2020 \\ Sent for revision: 6 November 2020 \\ Received in revised form: 15 November \\ Accepted: 29 November \\ Available online: 4 December 2020
}

\begin{abstract}
India announced its first National Telecom Policy in 1994 and since then its telecommunications Industry has witnessed tremendous growth. At a teledensity of $89.92 \%$ (TRAI 2019), it is the second largest telecom market in the world. The policy maker, Department of Telecommunication (DoT) and the regulator, Telecom Regulatory Authority of India (TRAI) have taken several initiatives to ensure affordable services to telecom users. TRAl also drives initiatives to increase the level of awareness about telecom industry among users. To analyse impact of these initiatives by TRAI and DoT, this study presents an objective assessment of user's awareness and their assessment of affordability of telecom services. A structured questionnaire is used to collect data by surveying a sample of 408 telecom users. It was found that half of the respondents were aware of DoT; more than half were aware of the regulator TRAI and Indian governments vision for telecommunications and $85 \%$ of survey respondents found telecom services affordable. The level of affordability varied across gender, age group and education levels. Through regression analysis, the study found that awareness about telecom industry influences users' assessment of service affordability. Hence, TRAI and DoT should take actions to increase the level of awareness, which will improve users' perception of affordability and may lead to increased adoption of telecom services. In
\end{abstract}

${ }^{1}$ School of Business Management and Commerce, MVN University, India, netra.singh@gmail.com

${ }^{2}$ Aligarh Muslim University, Aligarh, India

${ }^{3}$ Faculty of Management Studies, Aligarh Muslim University, Aligarh, India 
addition, it is suggested that affordability of female users can be addressed through customized tariff plan and schemes.

Keywords: Awareness, Telecommunications, TRAI, DoT, Affordability, Policy, Regulation.

\section{Procena nivoa svesti korisnika o indijskoj industriji telekomunikacija i njihova procena pristupačnosti telekomunikacionih usluga u Indiji}

Apstrakt: Indija je objavila svoju prvu nacionalnu telekomunikacionu politiku 1994. godine i od tada njena telekomunikaciona industrija beleži izrazit rast. Sa pokrivenošću od 89,92\% (TRAl 2019), to je drugo najveće tržište telekomunikacija na svetu. Kreator politike, Odeljenje za telekomunikacije (DoT) i regulator, Indijsko regulatorno telo za telekomunikacije (TRAI) preduzeli su nekoliko inicijativa kako bi korisnicima telekomunikacionih usluga obezbedili pristupačne usluge. TRAI takođe pokreće inicijative za povećanje nivoa svesti o ovoj industriji među korisnicima. Da bi se analizirao uticaj ovih inicijativa od strane TRAI i DoT, ova studija predstavlja objektivnu procenu svesti korisnika $i$ njihovu procenu pristupačnosti telekomunikacionih usluga. Strukturirani upitnik korišćen je za prikupljanje podataka anketiranjem uzorka od 408 korisnika telekomunikacionih usluga. Utvrđeno je da je polovina ispitanika bila upoznata sa DoT; više od polovine bilo je upoznato sa regulativom TRAI i vizijom indijske vlade u oblasti telekomunikacija, a $85 \%$ ispitanika smatra da su telekomunikacione usluge pristupačne. Nivo pristupačnosti varirao je u zavisnosti od pola, starosne grupe i nivoa obrazovanja. Kroz regresionu analizu, studija je otkrila da svest o telekomunikacionoj industriji utiče na procenu pristupačnosti usluga od strane korisnika. Stoga bi TRAI i DoT trebalo da preduzmu mere za povećanje nivoa svesti korisnika, što će poboljšati percepciju korisnika o pristupačnosti i može dovesti do većeg usvajanja ovih usluga. Pored toga, predlaže se da se povećanje nivoa pristupačnosti za ženske korisnike može rešiti kroz prilagođeni tarifni plan i šeme.

Ključne reči: Obaveštenost, Telekomunikacije, TRAI, DoT, Pristupačnost, Politika, Regulativa.

\section{Introduction}

India started revamp of its telecommunications sector with the launch of the National Telecom Policy in 1994 (NTP'94). From a dismal teledensity of 0.8 in 1994, India has reached the current teledensity of $89 \%$ (TRAI, 2019). The cellular mobile services have been the backbone of this growth with the private 60 
sector companies as major contributor (Economic Survey, 2019). The policy makers, regulators and telecom service providers have worked alongside and partnered in this journey. The Indian Policy maker and Telecom Regulator have taken several initiatives since telecom policy NTP'2014 to achieve the vision of providing available, affordable, reliable, secure and world-class telecom services to the end users.

India has one of the lowest telecom Average Revenue Per User (ARPU) in the world (ITU, 2018). The Telecommunications Industry, however, is under a debt of ₹7 Lakh crores ( $\sim 105$ Billion $\left.^{4}\right)(E T, 2019 a)$. There are intense tariff wars, post the entry of Reliance Jio in 2016. These tariff wars does benefit customer and influence the affordability of telecom services. There have been, however, unprecedented events in recent times. Bharti Airtel, one of the largest telecom companies in India, posted its first quarterly loss in 14 years (loss stood at ₹2,866 crores ( \$433 Million) for Q1'19 (BQ, 2019a). Vodafone Idea Limited posted a net loss of ₹4873.9 crores ( $\$ 732$ million) in Q2'19. Bharat Sanchar Nigam Limited (BSNL), the government PSU's, is struggling to pay salaries to the employees and its loss from business is estimated at ₹14,202 cores $(\$ 2.13$ Billion) for the FY'19 (ET, 2019a). Mahanagar Telephone Nigam Limited (MTNL) reported a loss of ₹832 cores ( $\$ 125$ million) in the third quarter of FY'19 (PTI, 2019a).

Whether such financial stresses are leading to modification of services is a subject to further research. However, based on the recent events, the telecom operators seem to be making efforts to mitigate the impact of such stresses. For Instance, Airtel and Vodafone Idea mandated ₹35 (USD 0.50) as the minimum recharge plan and discontinued all other recharges below this amount (Tandon, 2019). Airtel discontinued all postpaid plans below ₹499 (USD 7) and has halved the total number of postpaid offers (Khan, 2019). These initiatives directly impact the affordability and availability of services to users and TRAI had to intervene to secure user interests (ET, 2018). This study paper (through a survey) presents an assessment of affordability of telecom services in India, as perceived by the end users.

In order to ensure that telecom users are aware of various telecom related rights, developments and regulations, TRAI conducts customer outreach programmes, open house discussions etc. User awareness about both DoT and TRAI is important for the users to know their rights, know telecom related safeguards and make an objective assessment about functioning of these organizations. The study also makes an assessment of users' awareness about

\footnotetext{
${ }^{4} 1$ USD ₹ 66.5
} 
telecom industry in India and analyze whether user awareness impacts their assessment of affordability of services.

The objectives of this study are as follows:

1. To analyze the awareness of the telecom users about TRAI and DoT.

2. To analyze the awareness among users of telecom services about Indian Government's Vision for telecom services.

3. To analyze the awareness pattern across various demographics such as age, sex, occupation etc.

4. To provide assessment of the affordability of telecommunications services in India made by the end users.

5. To analyze relationship between telecom services user's awareness about telecom services and their assessment of affordability.

This paper starts with an introduction to the Indian telecommunications industry and research questions that paper addresses (Section 1). Section 2 provides background on the subject matter and contains an analysis of the literature which is used to support study approach and findings. Section 3 details the methodology including the statistical methods that were used for the analysis. Results and findings are presented in Section 4, which is followed by conclusion in Section 5.

\section{2. Background}

\subsection{Key policy initiates by Indian policy makers}

India launched its telecom policy called the National Telecom Policy in 1994 (NTP'94). With the teledensity at a dismal 0.8 in 1994, NTP'14 was aligned to achieve availability of services and promote universal services. In the second telecom policy called the New Telecom Policy 1999 (NTP'99) the policy makers added the dimension of affordable and effective communications. In the National Telecom Policy 2012 (NTP'12) policy makers came out with formal 'Vision' and 'Mission' for the telecommunication sector. NTP'12 stated the vision as "To provide secure, reliable, affordable and high-quality converged telecommunication services anytime, anywhere for an accelerated inclusive socio-economic development."

In the recently announced telecom policy called the National Digital Communications Policy - 2018 (NDPC'18), the government and policy makers presented a converged view by naming the telecom infrastructure as digital communications network. The revised vision is "To fulfill the information and communication needs of citizens and enterprises through the establishment of a ubiquitous, resilient, secure, accessible and affordable Digital Communications Infrastructure and Services; and in the process, support 
India's transition to a digitally empowered economy and society". Since NTP'99, providing affordable telecom services continues to be one of the focus areas for the government. This focus has resulted in call rates falling more than $96 \%$ from ₹15.32 ( USD 1)/ minute in 1998 to ₹0.48 ( 0.71 cent)/minute in 2016 (TRAI, 2017).

\subsubsection{Awareness of Telecommunications Industry}

In India, the telecom regulator TRAI has a specialized program called the "Consumer Outreach Programmes" for safeguarding consumer interests and creating consumer awareness. TRAI shares information with users on consumer centric regulations, directions and orders relating to telecom services and tariffs, etc. TRAI also appraises consumer satisfaction, makes recommendations to government and seek participation. TRAl's consultation process thereby is becoming a part of the policy making process (TRAI, 2018). Till 25 th October, 2019, TRAl has conducted 142 Consumer Outreach Programmes, 489 workshops, 131 open house discussion and 23 seminars with the stakeholders on various aspects to telecom. One of the objectives of this study paper is to make an assessment of the awareness level of the telecom users in India, so that TRAI and other agencies can make use of the outcome for any course correction.

\subsection{Assessing awareness via surveys}

Surveys conducted by using structured questionnaire are widely used for collecting data from end users. Utilities companies, marketing organizations, research agencies, health care agencies, telecom organizations, etc. use customer survey to collect data from end users. OECD, ITU and Telecom Regulators (like FCC, Ofcom, Australian Communications and Media Authority, TRAI etc.) widely use user surveys to collect data on awareness, quality of services and gaining specific feedback on telecommunications. Survey is extensively used in marketing, especially in collecting data on brand awareness, campaigns, pricing and plans etc.

\subsection{Measuring affordability}

Affordability, in its simplest form, represents ability of an average household within a population to pay for a particular service. There is, however, no single metric that is universally accepted to measure affordability (David, 2015). There are various framework and methodologies requiring standardization (Niens \& Brouwer, 2012). Two widely used methods are based on concept of impoverishment (population going below poverty line after spending) and 
catastrophic spending (need to spend beyond a certain percentage of income) (Wagstaff \& Doorslaer, 2003). ITU uses a basket of services approach wherein cost of standard service basket, as a percentage of gross income per capita, is used as a measure (ITU, 2012).

Affordability which is specific for utilities can be measured as a ratio of expenditure on utilities on total expenditure. Living Standard Measurement Surveys have also been used widely for measuring affordability (Fankhauser \& Tepic, 2005). In telecommunications, economists believe that affordable service can be provided only when the revenues are sufficient. Academics and practitioners from technical fields view affordability in terms of using low-cost technology (Milne, 2006). Gan \& Hill (2008) proposed three aspects of affordability - purchase affordability (ability to get fund to spend), repayment affordability and income affordability (spend to income) (Gan \& Hill, 2008). Authors used survey questions to gather data on affordability. The questions were based on impoverished method, catastrophic method and the concept of purchase and income affordability.

\subsubsection{Awareness drives perception}

Studies have found that awareness drives perception (Aaker, 1996; Dretske, 2006; Yoon, 2002; Yoo \& Donthu, 2002 as quoted in Hou, 2014; Chinedu, 2008 as quoted in Onukogu, 2018; Hughes \& Fernandez-Duque, 2010; Irvin 1985). Perception, in turn, may drive judgment (Chaudhuri \& Holbrook, 2001; Chiou \& Droge, 2006; Floh \& Treiblmaier, 2006; Rios \& Riquelme, 2008 as quoted in Hou, 2014; Onukogu, 2018; Akkaya, 2017). Authors have used finding from these studies to frame questions to assess users' perception of affordability of telecom services in India.

\subsection{Assessing regulatory and policy outcome}

There is a comprehensive body of literature demonstrating the positive impact of policies on telecom services, such as increased availability, quality of services and affordability of telecom services to end users (Katz, 2009; Kunigami \& Sabater, 2010; ITU, 2002; Symeou \& Pollitt, 2007; Hassan, 2011; Roller \& Waverman, 2001; Telecommunication Regulation Handbook, 2011; Thillairajan, Mahalingam \& Deep, 2013; Noam, 2010; ITU, 2018c; Melody, 1999; Wallsten, 1999; Fink, Mattoo \& Rathindran, 2002). Policy and regulatory initiatives can ensure equitable, universal and quality access of telecom services to customers through facilities based completion, regulation, interventions and so on (Bouckaert et al., 2010; Gruber \& Koutroumpis, 2012; 
Andrés, Cuberes \& Diouf, 2008; Kar \& Gupta, 2017; Abu, 2014; Noam, 2010; Melody, 1999; Bomsel, Cave, Blanc \& Neumann, 2003).

For capturing the customer perception of the telecommunications services, countries use operational reports, customer surveys and Quality of Services (QoS) reports provided by the operators. The ITU conducts survey among users in various countries and publishes "ICT Regulatory Tracker" on periodic basis (ITU, 2018a). ITU study groups publish assessments and findings from survey on quality aspects of regulatory framework of member countries (ITU, 2018b). OECD also does survey but at country level. Ofcom in UK publishes "Customer Satisfaction Tracker" based on customer survey. FCC, the US regulator, has a dedicated "Consumer Data Center" on quality related aspects of telecommunication services. FCC also uses consumer survey to assess service-related aspects.

In India, TRAI uses consultation to assess the policies which are being framed, and also to assess the impact of existing policies. These metrics are collected in terms of responses from the industry against the consultation papers. The TRAI manages the process of consultation on tariff, tariff recommendation and directions related to telecom tariff to the industry stakeholders. In effect, it directly influences the affordability of telecom services for end users. Out of the 475 transactions (Table 1 below) by TRAI till Q2'2019, maximum (112) are within the area of telecom tariff. This indicates that the focus of regulator is on ensuring affordability of services.

Table 1. Details of Initiatives by TRAI in Telecom Industry in India

\begin{tabular}{|l|l|c|c|c|l|}
\hline \multirow{2}{*}{$\begin{array}{c}\text { Initiatives by TRAI } \\
\text { (\#count\#) }\end{array}$} & \multicolumn{5}{|c|}{ Regulatory Initiatives (\#count) } \\
\cline { 2 - 6 } & Tariff & Interconnection & $\begin{array}{l}\text { Quality of } \\
\text { Service }\end{array}$ & Spectrum & $\begin{array}{l}\text { Licens } \\
\text { ing }\end{array}$ \\
\hline Consultation & 30 & 26 & 17 & 27 & 41 \\
\hline Recommendation & - & 15 & 6 & 58 & 40 \\
\hline Regulation & 69 & 42 & 32 & - & 4 \\
\hline Direction & 13 & 17 & 15 & 7 & 16 \\
\hline
\end{tabular}

Source: Compiled from data in TRAI website www.trai.gov.in

TRAI does a comprehensive audit cum validation of the QoS provided by the telecom operators (called Survey Reports). This is similar to the approach used in many countries such as Argentina, Japan, Portugal and Switzerland (ITU, 2018b). TRAI also gets third party surveys done from third party organizations (TRAI, 2010), (TUV, 2006), (Market Pulse, 2011). SERVQUAL and SERVPERF model and user survey using Likert scale have been widely used in such studies. These reports cover QoS of telecom services, but affordability is not explicitly monitored. Authors could not find an affordability assessment of 
telecom services being recently done by private sector or academia. This study attempts to bridge that gap and supplements the attempts made by the Indian telecom regulator, academia and other researchers in gauging end user satisfaction. This study is expected to provide valuable insight for the policy makers and regulators.

\section{Research methodology}

\subsection{Sampling unit and sample size}

The sampling frame consisted of users of telecommunications services in India. The individual user of the telecommunications services in India was the sampling unit. The sampling was done as a two-stage process. In the first stage, the authors used their contacts (telephone and What's app) as the primary sampling unit (convenience sampling). In the second step, each of the contacted users selected in first stage, collected data from users who were part of their contact list. In that sense, except the first stage, rest of the sampling was random in nature. Based on Cochran (1977) a minimum sample size of 384 was considered sufficient for this study (large population, maximum variability at $95 \%$ confidence level with $\pm 5 \%$ precision).

\subsection{Data collection}

Cross-sectional data collection was done through end user survey by using a structured questionnaire. The National Telecom Policy 1994, the New Telecom Policy 1999 and National Telecom Policy 2012 were studied in detail to frame the questions. These documents were the source of information on the priority that the Indian government gives to availability, affordability and quality of telecommunications services. The work of David (2015), Fankhauser et al. (2008) and Wagstaff et al. (2001) provided valuable insights in developing the questions for assessment of affordability of services.

\subsubsection{Pre-test}

In order to ensure that the questionnaire is clear, concise and consistent authors performed a pretest. Pre-test of the survey questionnaire was also done to assess the content validity of the measurement scales. Authors circulated the questionnaire among industry peers to get their valuable inputs and make the required correction. A review by five peers in the industry and academics was done and questions were added, deleted or modified. The experts also advised on changing the semantics of certain question and also reduced few questions, which they deemed duplicate or redundant. 


\subsubsection{Measures}

The survey questionnaire had 3 sections, which included 14 questions. These questions covered demographics of respondents, awareness about telecom services in India and their assessment of affordability of telecom services which are being provided in India. The questions on awareness included awareness about policy (Policy Awareness) and awareness about vision of telecom (Vision Awareness) in India. The Cronbach's Alpha for the questionnaire was 0.7. Chronbach's alpha value of $>0.5$ is acceptable in terms of internal consistency and reliability (Mohamad et al., 2018; Santos, 1999). All questions employed a five-point Likert scales anchored by ' 1 - strongly disagree', ' 5 - strongly agree' and ' 3 - neither agree nor disagree' as the midpoint.

\subsubsection{Data collection}

The questionnaire was distributed online and was hosted on a popular survey portal. Survey link was provided to each of the respondents, wherein the respondents could answer the questions by using phone or computer. The online questionnaire was designed to ensure that respondents do not skip any question and answer all of them. The online questionnaire also contained detailed instructions and meaning of abbreviations used in some of the questions.

\subsection{Data analysis}

Descriptive statistics and content analysis were carried out regarding the data pertaining to demographics. The user response on awareness questions were subjected to descriptive statistics and later to ANOVA to analyze the variations in relation to user demographics. Authors also did a factor analysis on the awareness related data to identify the factors, which could be subjected to further statistical treatment. The affordability related response was analyzed through descriptive statistics and ANOVA. In order to understand if user awareness was driving their assessment of affordability of telecom services, authors did a linear regression between the factors extracted from awareness related data and the response of affordability.

To analyze the relationship between awareness and affordability authors relied on the empirical findings that awareness drives perception (Aaker 1996) (Dretske, 2006) (Yoon, 2002) (Yoo \& Donthu, 2002 as quoted in Hou, 2014) (Chinedu, 2008 as quoted in Onukogu, 2018) (Hughes \& Fernandez-Duque, 2010) (Irvin 1985). The relationship between the Affordability Factors and Awareness Factor is conceptualized in the following form: 
Affordability $=f$ (awareness)

For the purpose of further analysis, the following linear regression equations were used.

Affordability $(A)=\beta_{0}+\beta_{1}$ (Policy Awareness $)+\varepsilon_{1}$

Affordability $(A)=\beta_{0}+\beta_{1}$ (Vision Awareness $)+\varepsilon_{1}$

In the above equations (2) and (3), $\beta_{0}$ is the intercept of the regression line and $\beta_{1}$ is the slope. Affordability $(A)$ is the estimated value of Affordability for a given value of Awareness.

Affordability is the dependent variable, which depends on user's awareness of policy and vision, which are the independent variable of this study.

\section{Results and discussion}

The survey questionnaires were distributed to more than 200 telecom users via email and WhatsApp messaging in the first stage. Authors relied on network externalities to take effect and found that many users selected in the first stage, sent it further to the people they knew. In all, 411 responses were received. All responses were individually reviewed and 3 responses were discarded, as these were not complete (in demographics section primarily). The remaining 408 responses were further analyzed for the purpose of this study.

\subsection{Demographics of the respondents}

Summarized demographic information of the respondents is presented in the Table 2. Eighty-two percent of the respondents were male and $18 \%$ were female. Regarding age, $95.1 \%$ of the respondents were older than 25 , while $57.6 \%$ of respondents were in the age group of 36-45. This age bracket would be the user who would have consistently used the services over the last few years and would have witnessed the level of telecom services over a period of time.

Regarding education level, more than $98.5 \%$ of the respondents was academic graduate and above, while $65 \%$ of the respondents were postgraduate and above. Of the total number, the occupation of $74.8 \%$ of the respondents were related to providing services, while remaining $26.2 \%$ of respondents were evenly spread across academia, business, studying, homemaking and business. This indicated that majority of respondents fell within the profile of most likely users of telecom services for personal and business use. They were 
well qualified to understand the survey questions and answer them in an objective manner.

The majority of respondents (42.2\%) were from Telecommunications/IT industry, followed by $10.5 \%$ of respondents from healthcare and pharmaceutical industry and $8.6 \%$ from the banking industry. These user groups can be considered as heavy user of telecom services owing to the nature of their work. Furthermore, $30 \%$ of the respondents hold senior level positions in their respective industry, while $12 \%$ of the respondents were technical experts in their respective fields. Teachers and academicians represented $3.9 \%$ of the total number of respondents. Students, who use telecom services liberally, constituted only $1 \%$ of the total responses. Finally, $7.4 \%$ of the respondents chose not to disclose their job role or designation.

Table 2. Descriptive statistics of survey respondents

\begin{tabular}{|c|c|c|c|c|c|c|c|c|c|}
\hline \multicolumn{9}{|c|}{ Gender } & \multirow[b]{2}{*}{ Total } \\
\hline Male & Female & & & & & & & & \\
\hline \multirow[t]{2}{*}{$\begin{array}{l}334 \\
(82) \\
\end{array}$} & $\begin{array}{l}74 \\
(18)\end{array}$ & & & & & & & & $\begin{array}{c}408 \\
(100)\end{array}$ \\
\hline & \multicolumn{7}{|c|}{ Age } & & \\
\hline$<=25$ & $26-35$ & $36-45$ & $46-55$ & $55+$ & & & & & Total \\
\hline \multirow[t]{2}{*}{$\begin{array}{c}20 \\
(4.9) \\
\end{array}$} & $\begin{array}{c}68 \\
(16.7)\end{array}$ & $\begin{array}{c}235 \\
(57.6)\end{array}$ & $\begin{array}{c}75 \\
(18.4)\end{array}$ & $\begin{array}{c}10 \\
(2.5)\end{array}$ & & & & & $\begin{array}{c}408 \\
(100)\end{array}$ \\
\hline & \multicolumn{8}{|c|}{ Academic Qualifications } & \\
\hline $\begin{array}{l}\text { 12th } \\
\text { std. }\end{array}$ & $\begin{array}{c}\text { Gradu } \\
\text { ate }\end{array}$ & $\begin{array}{c}\text { Maste } \\
r^{\prime} s\end{array}$ & $P G^{*}$ & Ph. D & & & & & Total \\
\hline \multirow[t]{2}{*}{$\begin{array}{c}6 \\
(1.5) \\
\end{array}$} & $\begin{array}{c}137 \\
(33.6) \\
\end{array}$ & $\begin{array}{c}105 \\
(25.7)\end{array}$ & $\begin{array}{c}152 \\
(37.3)\end{array}$ & $\begin{array}{c}8 \\
(2) \\
\end{array}$ & & & & & $\begin{array}{c}408 \\
(100)\end{array}$ \\
\hline & \multicolumn{8}{|c|}{ Occupation } & \\
\hline $\begin{array}{c}\text { Acade } \\
\text { mia }\end{array}$ & $\begin{array}{c}\text { Busin } \\
\text { ess }\end{array}$ & $\begin{array}{l}\text { Home } \\
\text { maker }\end{array}$ & $\begin{array}{c}\text { Profess } \\
\text { ional }\end{array}$ & $\begin{array}{c}\text { Servic } \\
e\end{array}$ & $\begin{array}{l}\text { Stud } \\
\text { ent }\end{array}$ & NR\# & & & Total \\
\hline \multirow[t]{2}{*}{$\begin{array}{c}17 \\
(4.2) \\
\end{array}$} & $\begin{array}{c}34 \\
(8.3)\end{array}$ & $\begin{array}{c}13 \\
(3.2)\end{array}$ & $\begin{array}{c}25 \\
(6.1)\end{array}$ & $\begin{array}{c}305 \\
(74.8)\end{array}$ & $\begin{array}{c}9 \\
(2.2)\end{array}$ & $\begin{array}{c}5 \\
(1.2)\end{array}$ & & & $\begin{array}{c}408 \\
(100)\end{array}$ \\
\hline & \multicolumn{8}{|c|}{ Industry } & \\
\hline $\begin{array}{l}\text { Telec } \\
\text { om /it }\end{array}$ & $B F S I^{*}$ & $\begin{array}{c}\text { Autom } \\
\text { obile }\end{array}$ & $\begin{array}{l}\text { Health/ } \\
\text { pharma }\end{array}$ & $\begin{array}{c}\text { Utilitie } \\
s\end{array}$ & $\begin{array}{l}\text { Tran } \\
\text { sport }\end{array}$ & Govt. & $\begin{array}{c}\text { Othe } \\
\text { rs }\end{array}$ & & Total \\
\hline \multirow[t]{2}{*}{$\begin{array}{c}172 \\
(42.2) \\
\end{array}$} & $\begin{array}{r}35 \\
(8.6) \\
\end{array}$ & $\begin{array}{c}4 \\
(1.0) \\
\end{array}$ & $\begin{array}{c}43 \\
(10.5) \\
\end{array}$ & $\begin{array}{c}9 \\
(2) \\
\end{array}$ & $\begin{array}{c}4 \\
(1.0)\end{array}$ & $\begin{array}{c}6 \\
(1.5)\end{array}$ & $\begin{array}{l}135 \\
\text { (33) }\end{array}$ & & $\begin{array}{c}408 \\
(100)\end{array}$ \\
\hline & \multicolumn{8}{|c|}{ Designation/Job Role } & \\
\hline ELM $^{*}$. & $\begin{array}{c}\text { Middle } \\
\text { mgt. }\end{array}$ & Owner & $\mathrm{SA}^{*}$ & $\begin{array}{c}\text { Senior } \\
\text { mgt. }\end{array}$ & $\begin{array}{c}\text { Senior } \\
\text { prof. }\end{array}$ & $\begin{array}{c}\text { Stud } \\
\text { ent }\end{array}$ & $\begin{array}{c}\text { Teac } \\
\text { her }\end{array}$ & $\mathrm{TE}^{*}$ & Total \\
\hline $\begin{array}{c}43 \\
(10.5) \\
\end{array}$ & $\begin{array}{c}121 \\
(29.7) \\
\end{array}$ & $\begin{array}{c}13 \\
(3.2) \\
\end{array}$ & $\begin{array}{c}7 \\
(1.7)\end{array}$ & $\begin{array}{c}125 \\
(30.6)\end{array}$ & $\begin{array}{c}7 \\
(1.7)\end{array}$ & $\begin{array}{c}4 \\
(1)\end{array}$ & $\begin{array}{c}9 \\
(2.2)\end{array}$ & $\begin{array}{c}49 \\
(12) \\
\end{array}$ & $\begin{array}{c}378 \\
(91.6) \\
\end{array}$ \\
\hline \multicolumn{10}{|c|}{$\begin{array}{l}\mathrm{BFSI}^{*}=\text { Banking, Financial Services and Insurance, } \mathrm{ELM}^{*}=. \text { Entry Level Management, SA } \\
=\text { Senior Academic, } \mathrm{TE}^{*}=\text { Technical Experts, NR\#=Not reported. Figures in parenthesis are } \\
\text { percentage }\end{array}$} \\
\hline
\end{tabular}

Source: Compiled by authors from data collected through the survey 


\subsection{Awareness about key aspects of Indian Telecommunications Industry}

The questionnaire on awareness had five questions, as detailed in Table 3. These include: awareness about the telecom policy maker (DoT) and its function, the regulator (TRAl) and its function, operators reporting obligation to TRAI and specific question regarding awareness of government's vision for telecom. Table 3 summarizes key descriptive statistics of the data collected. It was found that $50.5 \%$ of the respondents were aware that DoT is the policy maker and that DoT specifies the telecom services that can be provided in India (cumulative percentage of high and very high level of awareness). The Sample Mean was 3.55 and Median for the response data was 4, which mapped to high level of awareness. The standard error corresponding to Sample Mean for this question was 0.049 and with $95 \%$ confidence, it can be concluded that the Population Mean would fall between 3.59 and 3.5. This translates to the conclusion that awareness about DoT among the population is between average and high.

Table 3. Distribution of Respondents as per their awareness of the Indian Telecommunications Industry and Services

\begin{tabular}{|c|c|c|c|c|c|c|c|}
\hline \multirow[b]{2}{*}{ Statement } & \multicolumn{7}{|c|}{ Response Scale (Figures in parenthesis are \%age) } \\
\hline & $\begin{array}{l}\text { Very } \\
\text { Low }\end{array}$ & Low & $\begin{array}{l}\text { Avera } \\
\text { ge }\end{array}$ & High & $\begin{array}{l}\text { Very } \\
\text { High }\end{array}$ & $\begin{array}{l}\text { Mean } \\
\pm \mathrm{SE}\end{array}$ & $\begin{array}{l}\text { Med } \\
\text { ian }\end{array}$ \\
\hline $\begin{array}{lcc}\text { A1 } & \text { Aware of } \\
\text { Telecom Policy Maker }\end{array}$ & $\begin{array}{ll}15 \\
(3.7)\end{array}$ & $\begin{array}{l}29 \\
(7.1)\end{array}$ & $\begin{array}{l}158 \\
(38.7)\end{array}$ & $\begin{array}{l}127 \\
(31.1) \\
\end{array}$ & $\begin{array}{l}79 \\
(19.4) \\
\end{array}$ & $\begin{array}{l}3.55 \\
(0.05) \\
\end{array}$ & 4 \\
\hline $\begin{array}{lcc}\text { A2 - Aware of } \\
\text { Telecom Regulator }\end{array}$ & $8(2)$ & $\begin{array}{l}19 \\
(4.7) \\
\end{array}$ & $\begin{array}{l}106 \\
(26) \\
\end{array}$ & $\begin{array}{l}155 \\
(38) \\
\end{array}$ & $\begin{array}{l}120 \\
(29.4) \\
\end{array}$ & $\begin{array}{l}3.88 \\
(0.05) \\
\end{array}$ & 4 \\
\hline $\begin{array}{l}\text { A3 - Awareness of } \\
\text { Government's Vision } \\
\text { of Telecom for all }\end{array}$ & $\begin{array}{l}3 \\
(0.7)\end{array}$ & $\begin{array}{l}12 \\
(2.9)\end{array}$ & $\begin{array}{l}85 \\
(20.8)\end{array}$ & $\begin{array}{l}172 \\
(42.2)\end{array}$ & $\begin{array}{l}136 \\
(33.3)\end{array}$ & $\begin{array}{l}4.04 \\
(0.04)\end{array}$ & 4 \\
\hline $\begin{array}{l}\text { A4 - Awareness of } \\
\text { Government's Vision } \\
\text { of Service Availability }\end{array}$ & $\begin{array}{l}5 \\
(1.2) \\
\end{array}$ & $\begin{array}{l}18 \\
(4.4)\end{array}$ & $\begin{array}{l}114 \\
(29.7)\end{array}$ & $\begin{array}{l}158 \\
(38.7)\end{array}$ & $\begin{array}{l}113 \\
(27.7)\end{array}$ & $\begin{array}{l}3.87 \\
(0.05) \\
\end{array}$ & 4 \\
\hline $\begin{array}{l}\text { A5 - Awareness of } \\
\text { Operator's Obligation }\end{array}$ & $\begin{array}{l}14 \\
(3.4)\end{array}$ & $\begin{array}{l}22 \\
(5.4)\end{array}$ & $\begin{array}{l}94 \\
(23) \\
\end{array}$ & $\begin{array}{l}166 \\
(40.7) \\
\end{array}$ & $\begin{array}{l}112 \\
(27.5)\end{array}$ & $\begin{array}{l}3.83 \\
(0.05) \\
\end{array}$ & 4 \\
\hline
\end{tabular}

Source: Compiled by authors from data collected through the survey

Additionally, $67.4 \%$ of respondents knew about TRAI as being the regulatory body which monitors quality of service, tariff and consumer protection measures (cumulative percentage of high and very high level of awareness). The Sample Mean of awareness about TRAI was 3.88 with a SE of 0.047 . With $95 \%$ confidence, it can hence be concluded that the Population Mean of awareness about TRAI falls between 3.83 and 3.92 , which is better than 
average level of awareness and close to high level of awareness. In other words, awareness about TRAl is between average and high.

Furthermore, $75.5 \%$ of respondents indicated high level of awareness about Indian Government's vision to make telecom services available to everyone (cumulative percentage of high and very high level of awareness). The Sample Mean of responses was 4.04, which mapped to high level of awareness. When interpreted with SE of 0.042 , it can be concluded that Population Mean will lie between 4 and 4.08, which means high level of awareness. Hence awareness level among telecom users about Indian Government's vision to make telecom services available to everyone lies between high and very high.

Awareness about Indian Government's vision to provide reliable and secure telecom services anytime, anywhere were high, since $66.4 \%$ of respondents indicated their awareness between high and very high (cumulative percentage of high and very high level of awareness). With a Sample Mean of response at 3.87 and SE of 0.045 , the Population Mean (at 95\% confidence) would fall between 3.91 and 3.82. Thus, awareness of population about Indian Government's vision to provide reliable and secure telecom services anytime anywhere lies between average and high.

More than $68.2 \%$ of respondents indicated high level of awareness about Telecom Service provider needing to report its performance statistics to TRAI (cumulative percentage of high and very high level of awareness). The Sample Mean for the awareness level was 3.83 and with SE of 0.05 , it can be concluded that the Population Mean would lie between 3.78 and 3.88. Therefore, the population awareness about Telecom Service provider needing to report its performance statistics to TRAI lies between average and high.

\subsubsection{Comparative analysis of user awareness of telecom industry across different demographics}

Many studies have found that demographics have an impact on mobile services usage (Watson, et al., 2015; Sillice, et al., 2018; Sarraute, et al., 2014). In the context of India, there are only $17.4 \%$ female mobile users (Rathee, 2018) and less than $25 \%$ of females have access to mobile phones (Barboni, et al., 2018) (GSMA, 2018). Since this gender gap directly relates to policy makers and regulators vision of equal access, author also analyzed the level of awareness among various demographics. ANOVA at $95 \%$ confidence level was carried and results are presented in the following table. Interpretation of Table 4 is given in the subsequent sections. 
Table 4. ANOVA based p-values for different demographics of the Indian Telecommunications Industry and Services

\begin{tabular}{|l|l|l|l|l|l|l|}
\hline \multirow{2}{*}{ Statement } & \multicolumn{2}{|l|}{ - value (0.05) } \\
\cline { 2 - 7 } & $\begin{array}{l}\text { Gen } \\
\text { der }\end{array}$ & Age & $\begin{array}{l}\text { Edu. } \\
\text { Qualifi } \\
\text { cation }\end{array}$ & $\begin{array}{l}\text { Occupat } \\
\text { ion }\end{array}$ & $\begin{array}{l}\text { Indust } \\
\text { ry }\end{array}$ & $\begin{array}{l}\text { Design } \\
\text { ation }\end{array}$ \\
\hline $\begin{array}{l}\text { A1 - Aware of Telecom } \\
\text { Policy Maker }\end{array}$ & 0.04 & 0.006 & 0.474 & 0.000 & 0.0004 & 0.042 \\
\hline $\begin{array}{l}\text { A2 - Aware of Telecom } \\
\text { Regulator }\end{array}$ & $\begin{array}{l}0.00 \\
2\end{array}$ & 0.429 & 0.198 & 0.001 & 0.134 & 0.001 \\
\hline $\begin{array}{l}\text { A3 - Awareness of } \\
\text { Government's Vision of } \\
\text { Telecom for all }\end{array}$ & 0.06 & 0.217 & 0.829 & 0.464 & 0.136 & 0.039 \\
\hline $\begin{array}{l}\text { A4 - Awareness of } \\
\text { Government's Vision of } \\
\text { Service Availability }\end{array}$ & 0.31 & 0.250 & 0.349 & 0.694 & 0.135 & 0.014 \\
\hline $\begin{array}{l}\text { A5 - Awareness of } \\
\text { Operator's Obligation }\end{array}$ & $\begin{array}{l}0.01 \\
0\end{array}$ & 0.120 & 0.854 & 0.016 & 0.001 & 0.043 \\
\hline
\end{tabular}

Source: Compiled by authors from data collected through the survey

\subsubsection{Comparative analysis of user awareness of telecom industry based on gender}

Authors observed statistically significant difference in the level of awareness between male and female users with regard to awareness about DoT and TRAI. There was no statistically significant difference in the level of awareness among male and female respondents about Indian Government's vision for making telecom services available to everyone. Similarly, there was no statistically significant difference in awareness level of male and female respondent with respect to Indian government's vision to provide reliable and secure telecom services anytime, anywhere (For these two statements $p$ value is greater than 0.05). However statistically significant difference in level of awareness among male and female respondents was found in terms of awareness about obligation of telecom Service provider to report their performance statistics to TRAI.

4.2.2.2 Comparative analysis of user awareness of telecom industry across age groups

Level of awareness about the policy maker DoT and TRAI was not statistically significant among different age groups. Similarly, no statistically significant difference was found in the level of awareness between different age group about government's vision on telecom. Age group was also not found to be statistically significant in terms of awareness about telecom operator's obligation to report performance to TRAI. This is an important indicator 72 
signifying the situation that young and educated people are generally perceived to be more aware of the market and industries.

\subsubsection{Comparative analysis of user awareness of telecom industry across different educational qualifications}

No statistically significant difference in the level of awareness about DoT and TRAI was found across different education levels. Authors also found no statistically significant differences in the level of awareness about government's vision on telecom between different education groups. Education level also did not influence the level of awareness about telecom operator's obligation to report performance to TRAI. This can mean that higher levels of education do not translate into higher level of awareness as far as telecom services in India are concerned and vice-versa. These can be an important indicator for TRAI to review its consumer awareness program in terms of target audience. For all groups, $p$ value is greater than 0.05 .

4.2.2.4 Comparative analysis of user awareness of telecom industry across different occupations

Statistically significant difference in awareness level about DoT and TRAI is found across different occupations. The level of awareness about Indian government's vision of telecom services did not vary based on occupation, but statistically significant difference in awareness level was found about telecom operator's obligation to submit performance reports to TRAI. Across all questions on awareness, authors found highest average level of awareness of respondents whose occupation relates to services, while the lowest average level of awareness was found among students. Since the number of respondents employed in service sectors were also the highest, it cannot be concluded that students would be less aware. The data, however, indicated that average level of awareness was falling when moving from professionals to homemakers and finally to students.

4.2.2.5 Comparative analysis of user awareness of telecom industry across respondent groups working in different industries

Respondents from different industries were found to have different levels of awareness about DoT and its function. There was, however, no statistically significant difference in awareness level about TRAl and its function and awareness about Indian government's vision on telecommunications. Authors found statistically significant difference in awareness level about operator's obligation of reporting performance to TRAI across respondents from different industries. It is likely that respondents working in telecom industry would be more aware compared to respondents from pharmaceutical industry. This can 
be attributed to the fact that it is a generally more likely that a person working in certain industry will be more aware of the agencies active therein.

4.2.2.6 Comparative analysis of user awareness of telecom industry across designation/job roles

Respondents across various designation/role demonstrated statistically significant differences in awareness levels across all questions. The awareness level varied across designation/role about DoT and its function, TRAI and its function, Indian government's vision for telecom and operator's obligation of reporting performance to TRAI. Respondents belonging to senior management level were found to have higher level of awareness on average compared to respondents from entry level of management. Students were found to have lower average level of awareness, but this cannot be conclusive since the number of students in the sample was also less.

\subsection{User assessment of affordability of telecom services in India}

Authors explicitly asked respondents if telecommunication services in India are affordable (hereinafter called "Affordability Verdict"). The descriptive statistics of the data thus collected is presented in Table 5 . It was found that $85.8 \%$ of the respondents agreed (cumulative of agree and strongly agree responses) that the telecom services are affordable in India. With Sample Mean of 4.04 and SE of 0.039 , the Population Mean can be expected to lie between 4.00 and 4.08 (based on $95 \%$ confidence level). In other words, it can be concluded, with $95 \%$ confidence, that the population also finds the telecom services affordable.

Table 5. Distribution of respondents as per their agreement on Policy and Regulation outcome for the Indian Telecommunications Industry and Services

\begin{tabular}{|l|l|l|l|l|l|l|l|}
\hline Statement & $\begin{array}{l}\text { Strong } \\
\text { ly } \\
\text { Disagr } \\
\text { ee=1 }\end{array}$ & $\begin{array}{l}\text { Disagr } \\
\mathbf{e e = 2}\end{array}$ & $\begin{array}{l}\text { Neither } \\
\text { Agree } \\
\text { Nor } \\
\text { Disagree } \\
\mathbf{= 3}\end{array}$ & $\begin{array}{l}\text { Agree } \\
\mathbf{= 4}\end{array}$ & $\begin{array}{l}\text { Strongl } \\
\mathbf{y} \\
\text { Agree= } \\
\mathbf{5}\end{array}$ & $\begin{array}{l}\text { Mean } \mathbf{\pm} \\
\text { SE }\end{array}$ & $\begin{array}{l}\text { Media } \\
\mathbf{n}\end{array}$ \\
\hline $\begin{array}{l}\text { O1 - } \\
\begin{array}{l}\text { Telecommunicatio } \\
\text { n services in India } \\
\text { are Affordable. }\end{array}\end{array}$ & $\begin{array}{l}5 \\
(1.2)\end{array}$ & $\begin{array}{l}19 \\
(4.7)\end{array}$ & $\begin{array}{l}34 \\
(8.3)\end{array}$ & $\begin{array}{l}246 \\
(60.3)\end{array}$ & $\begin{array}{l}104 \\
(25.5)\end{array}$ & $\begin{array}{l}4.04 \\
(0.04)\end{array}$ & 4 \\
\hline
\end{tabular}

Source: Compiled by authors from data collected through the survey

\subsubsection{Comparative analysis of user assessment of affordability of telecom services in India across different demographics}

Impact of demographics on affordability has been established across various studies. Affordability impacts accessibility and usage of services across various 74 
industries including telecommunications (Anderson, 1973; Walsh, 2015; Jain \& Sridhar, 2003). In the context of India, there is a difference in access of telecom services depending on demographics. Affordability of the services may be one of the reasons for such inequality in access. To analyze if responses on affordability varies across demographics, authors carried out ANOVA between groups and the results from the ANOVA test are presented in Table 6.

Table 6. ANOVA based p-values for different demographics on questions related to outcome of policy and regulatory initiatives

\begin{tabular}{|l|l|l|l|l|l|l|}
\hline $\mathrm{p}$ - value (0.05) & Gender & Age & $\begin{array}{l}\text { Educational } \\
\text { Qualification }\end{array}$ & $\begin{array}{l}\text { Occup } \\
\text { ation }\end{array}$ & $\begin{array}{l}\text { Indust } \\
\text { ry }\end{array}$ & $\begin{array}{l}\text { Designa } \\
\text { tion/Job } \\
\text { Role }\end{array}$ \\
\hline $\begin{array}{l}\text { O1 - } \\
\text { Telecommunic } \\
\text { ation services } \\
\text { in India are } \\
\text { Affordable. }\end{array}$ & 0.04 & 0.93 & 0.01 & 0.176 & 0.153 & 0.005 \\
\hline
\end{tabular}

Source: Compiled by authors from data collected through the survey

4.3.1.1 Comparative analysis of user assessment of affordability of telecom services in India based on gender

Authors observed statistically significant differences in Affordability verdict between male and female. With mean score of 3.8 (on affordability) versus 4.1, it was shown that female users (respondents) perceive telecommunications services as less affordable than their male counterparts. Interestingly, only $16 \%$ of female respondents were homemakers or persons who may not have a direct source of income. Considering the fact that $84 \%$ of earning female respondents find telecom services to be less affordable in comparison to their male counterparts, this area needs further examination. The response data revealed that more than $50 \%$ of the female respondents reside in tier- 1 Indian cities and the mean of affordability assessment for such respondents was 3.8. On the other hand, the mean of affordability assessment was 3.9 for the remaining female respondents. This points out the situation that female users residing in cities other than tier- 1 find telecom services to be more affordable than female respondents in tier-1 cities. This finding opposes the natural wisdom as tier-1 cities are expected to have higher level of income and hence affordability. 


\subsubsection{Comparative analysis of user assessment of affordability of telecom services in India based on age groups}

No statistically significant difference was found on the verdict on affordability of telecom services in India across different age groups. This finding needed further analysis, as normal wisdom would suggest that affordability should vary in age groups due to level of income. Telecom users below the age of 25 and above the age of 55 are expected to have limited source of income and hence limited affordability. However, these users constituted only $30 \%$ of the total number of responses. In addition, the affordability assessment of users above the age group of 55 has a mean of 4.3 , which was close to the mean value across all respondents. This may be one of the reasons which would have caused the ANOVA to indicate no difference in affordability assessment across age groups.

\subsubsection{Comparative analysis of user assessment of affordability of telecom services in India across different educational groups}

The response on affordability showed statistically significant difference across different educational qualifications. Respondents who have Post Garduate or Master's related qualificaition found the telecom services to be most affordable. Respondents with qualification up to graduate level found the telecom services to be less affordable. This is in line with the natural wisdom that higher education may lead to higher level of income and hence higher affrodability. Surprisingly, the mean affordability assessment for respondents with doctorate was lower compared to respondents with Masters and Post graduate qualification. In further analysis, authors found that the only $2 \%$ of the total respondents (only 8 out of total 408 respondents) have doctorate level and that, actually, response from one of the respondents caused the decrease of the overall mean score.

\subsubsection{Comparative analysis of user assessment of affordability of telecom services in India based on respondents' occupation}

The ANOVA result did not indicate any statistically significant difference in the verdict of respondent across various occupations. It would be expected ANOVA to indicate differences as educational qualification influenced user assessment of affordability. Since education is expected to define someone's occupation, differences in assessment of affordability across occupation groups would be expected. Further analysis of data revealed that $74 \%$ of the respondents belong the occupational group of "Service". The mean affordability assessment score was 4 for this group, which is almost same as the mean score for homemakers, 
students and professionals. This uniformity was reflected in the ANOVA results indicating no variation in assessment based on occupation.

\subsubsection{Comparative analysis of user assessment of affordability of telecom services in India across industries respondents work in}

Similar to the results obtained for occupation, the result of ANOVA did not indicate any statistically significant difference in the verdict of respondent across Industry. Respondents working for Automobile Industry and Government organization found to be telecom services less affordable than the rest of the group. These respondents make only $10 \%$ of the overall sample and represent only two out of eight industrial sectors that were analyzed. Since eight industrial sectors have similar mean affordability score, the variance across industry came out not to be statistically significant. There is a scope of further research to ascertain if respondents in automotive industry and government sector represent an income segment, which is different from other industries.

\subsubsection{Comparative analysis of user assessment of affordability of telecom services in India across designation/job role}

The ANOVA on responses across various categories of designation showed statistically significant difference on verdict on affordability of the telecom services. This outcome was as income levels differ across designations within the industry and across industries. Senior management represents $30 \%$ of the responses, followed by middle management with $29 \%$ and entry level management with $10 \%$ of responses. In other words, the assessment was spread across the various designation and with $70 \%$ spread across significantly different income groups, it would be expected the ANOVA to suggest difference in assessment of affordability across designation.

\subsection{Factors driving user awareness}

Questionnaire included five questions on awareness. These five questions were within the dimensions of 'awareness about regulator', 'awareness about policy makers' and 'awareness of telecom users about Indian government's vision on telecom'. To ascertain if there are common underlying factors, authors carried out Kaiser-Meyer-Olkin (KMO) and Bartlett's test of sphericity. The KMO and Bartlett's tests indicated that a factor analysis using Varimax rotation might be useful (Taherdost et al., 2014; Chan \& Idris, 2017). 


\subsubsection{Factor Analysis of the response data on Awareness (A1-A5)}

The outcome of the factor analysis is presented in the Table 7 . The response data on the five questions on awareness loaded into two Factors. Response data on three questions related to policy maker and regulator loaded into Factor 1 (hereafter called Policy Awareness). The response data on the remaining two questions related to government vision loaded into the second Factor 2 (hereafter called Vision Awareness). These two factors explained more than $75 \%$ of variance.

Table 7. Factor analysis-rotational component matrix and communality (Awareness dimension)

\begin{tabular}{|c|c|c|c|c|c|c|c|}
\hline Dimension & Definition & Fact & Fact & Comm & KM & Bartle & test \\
\hline $\begin{array}{l}\text { A1 - Aware of } \\
\text { Policy Maker }\end{array}$ & $\begin{array}{l}\text { DoT is the policy } \\
\text { maker who } \\
\text { specifies what } \\
\text { telecom services } \\
\text { can be provided. }\end{array}$ & 0.873 & 0.172 & 0.791 & $\begin{array}{l}0.81 \\
1\end{array}$ & $\begin{array}{l}\text { Appro } \\
\text { x. Chi- } \\
\text { Squar } \\
\text { e }\end{array}$ & $\begin{array}{l}850.23 \\
2\end{array}$ \\
\hline $\begin{array}{l}\text { A2 - Aware of } \\
\text { Regulator }\end{array}$ & $\begin{array}{l}\text { TRAI is the } \\
\text { regulator who } \\
\text { monitors quality of } \\
\text { service, tariff and } \\
\text { consumer } \\
\text { protection } \\
\text { measures. }\end{array}$ & 0.765 & 0.377 & 0.727 & & $\begin{array}{l}\text { Degre } \\
\mathrm{e} \text { of } \\
\text { freedo } \\
\mathrm{m}\end{array}$ & 10 \\
\hline $\begin{array}{l}\text { A3 - Awareness } \\
\text { of Govt Vision of } \\
\text { Telecom for all }\end{array}$ & $\begin{array}{l}\text { Indian Government' } \\
\text { s vision is to make } \\
\text { telecom services } \\
\text { available to } \\
\text { everyone. }\end{array}$ & 0.318 & 0.869 & 0.855 & & $\begin{array}{l}\text { Signifi } \\
\text { cance }\end{array}$ & 0 \\
\hline $\begin{array}{l}\text { A4 - Awareness } \\
\text { of Govt Vision of } \\
\text { Service } \\
\text { Availability }\end{array}$ & $\begin{array}{l}\text { Government's } \\
\text { vision is to provide } \\
\text { reliable and secure } \\
\text { telecom services } \\
\text { anytime, anywhere. }\end{array}$ & 0.283 & 0.881 & 0.855 & & & \\
\hline $\begin{array}{l}\text { A5 - Awareness } \\
\text { of Operator's } \\
\text { Obligation }\end{array}$ & $\begin{array}{l}\text { Telecom Service } \\
\text { provider needs to } \\
\text { report its } \\
\text { performance } \\
\text { statistics to TRAI. }\end{array}$ & 0.631 & 0.394 & 0.553 & & & \\
\hline \multicolumn{2}{|c|}{ Total Variance Explained (\%) } & 62.05 & 13.58 & & & & \\
\hline \multicolumn{2}{|c|}{ Cumulative Variance Explained (\%) } & 62.05 & 75.63 & & & & \\
\hline
\end{tabular}

Source: Compiled by authors from data collected through the survey 


\subsection{Are awareness factors driving user assessment of affordability of telecom services in India?}

Many studies have found that awareness drives perception (Aaker, 1996; Dretske, 2006; Yoon, 2002; Yoo \& Donthu, 2002 as quoted in Hou, 2014; (Chinedu, 2008 as quoted in Onukogu, 2018; Hughes \& Fernandez-Duque, 2010; Irvin 1985). Perception, in turn, may drive judgment (Chaudhuri \& Holbrook, 2001; Chiou \& Droge, 2006; Floh \& Treiblmaier, 2006; Rios \& Riquelme, 2008 as quoted in Hou, 2014; Onukogu, 2018; Akkaya, 2017).

As a first step to establishing a relationship between Awareness factor and Affordability factor, authors performed correlation. Authors performed Pearson Correlation and found significant correlation between awareness factors and Affordability verdict. The results of the correlation analysis are presented in Table 8. Scatter plots were also drawn between the factors to see the level of correlation and if regression was going to make statistically significant impact on the objective (Friendly \& Denis, 2005).

Table 8. Correlations between Awareness Factor and Affordability verdict

\begin{tabular}{|l|l|l|l|l|}
\hline \multicolumn{2}{|c|}{} & $\begin{array}{l}\text { Policy } \\
\text { Awareness }\end{array}$ & $\begin{array}{l}\text { Vision } \\
\text { Awareness }\end{array}$ & $\begin{array}{l}\text { Affordability } \\
\text { Verdict }\end{array}$ \\
\hline $\begin{array}{l}\text { Policy } \\
\text { Awareness }\end{array}$ & $\begin{array}{l}\text { Pearson } \\
\text { Correlation }\end{array}$ & 1 & 0.000 & $\mathbf{0 . 1 3 2}^{* *}$ \\
\cline { 2 - 5 } & $\begin{array}{l}\text { Sig. (2- } \\
\text { tailed) }\end{array}$ & & 1.000 & 0.008 \\
\hline $\begin{array}{l}\text { Vision } \\
\text { Awareness }\end{array}$ & $\begin{array}{l}\text { Pearson } \\
\text { Correlation }\end{array}$ & 0.000 & 1 & $\mathbf{0 . 2 2 2}^{\text {** }}$ \\
\cline { 2 - 5 } & $\begin{array}{l}\text { Sig. (2- } \\
\text { tailed) }\end{array}$ & 1.000 & 0.000 \\
\hline $\begin{array}{l}\text { Affordability } \\
\text { Verdict }\end{array}$ & $\begin{array}{l}\text { Pearson } \\
\text { Correlation }\end{array}$ & $\mathbf{0 . 1 3 2 *}$ & $\mathbf{0 . 2 2 2 * *}$ & 1 \\
\cline { 2 - 5 } & $\begin{array}{l}\text { Sig. (2- } \\
\text { tailed) }\end{array}$ & 0.008 & 0.000 & \\
\hline$* *$. Correlation is significant at 0.01level (2-tailed). & & \\
\hline
\end{tabular}

Source: Based on analysis of data collected through user survey

To analyse the type of relationship between Awareness factor and Affordability Factor, scatter plots were drawn. The scatter plots (figure 1 and figure 2 in Appendix A) revealed a linear relationship between Affordability Factor and Awareness Factor. This further strengthened the model, which authors detailed in section 3.3, wherein authors assumed linear relation between Affordability Factors and Awareness Factor for regression analysis. 


\subsubsection{Affordability Verdict as dependent variable}

The regression between Affordability Verdict as dependent variable and the Awareness Factors as independent variable (Policy and Vision Awareness) had $R^{2}$ and Adjusted $R^{2}$ value of 0.067 and 0.062 respectively (Table 9). The standardized coefficients for both Policy Awareness and Vision Awareness were significant. Since the Adjusted $\mathrm{R}^{2}$ value and significant coefficient were not leading to a conclusion, further analysis through scatter plots was done (Grace-Martin, 2012).

The scatter plots (as shown in Appendix-A) revealed significant clustering of Policy Awareness and Vision Awareness values around the line of fit. There was, however, two sets of clustering of values in both cases of Policy Awareness and Vision Awareness. One set of values clustered around the line of fit and the other set of values clustered slightly above the line of fit in both cases. The first group of cluster along the line of fit represented telecom users where level of awareness and their assessment of affordability were aligned. For the second group of users, for the same level of awareness, their assessment of affordability was high. In both the cases, a clear relationship between awareness of the user about telecom and their assessment of affordability of telecom services was found (Moore et al., 2013).

Hence, users' awareness about Policy and Vision of telecom impacted their user verdict on Affordability of telecom services. As noticed in the scatter plot, as the affordability assessment varies for the same level of awareness, the predictability of affordability by the awareness factors suffers from high level of variability. This is reflected in the low Adjusted $\mathrm{R}^{2}$ value of the regression model. It is possible that a larger sample and inclusion of other variables related to affordability and awareness can result in a better model fit (Itaoka, 2012; Reisinger, 1997).

Table 9. Output of Regression between Affordability Verdict and Awareness Factors

\begin{tabular}{|l|l|l|l|l|}
\hline Model Summary & \multicolumn{3}{l|}{} \\
\hline Model & R & R Square & Adjusted R Square & Std. Error of the Estimate \\
\hline 11 & $.259^{\mathrm{a}}$ & .067 & .062 & .96834235 \\
\hline
\end{tabular}

\begin{tabular}{|c|c|c|c|c|c|c|}
\hline \multicolumn{7}{|c|}{ Coefficients } \\
\hline \multirow{2}{*}{\multicolumn{2}{|c|}{ Model }} & $\begin{array}{l}\text { Unstandarc } \\
\text { Coefficient }\end{array}$ & $\begin{array}{l}\text { dized } \\
\text { s }\end{array}$ & $\begin{array}{l}\text { Standardized } \\
\text { Coefficients }\end{array}$ & \multirow[b]{2}{*}{$\mathrm{t}$} & \multirow[b]{2}{*}{ Sig. } \\
\hline & & $B$ & Std. Error & Beta & & \\
\hline \multirow{3}{*}{$11 a$} & (Constant) & $-4.291 \mathrm{E}-16$ & .048 & & .000 & 1.000 \\
\hline & $\begin{array}{l}\text { Policy } \\
\text { Awareness }\end{array}$ & .132 & .048 & .132 & 2.753 & .006 \\
\hline & $\begin{array}{l}\text { Vision } \\
\text { Awareness }\end{array}$ & .222 & .048 & .222 & 4.633 & .000 \\
\hline
\end{tabular}

Source: Based on analysis of data collected through user survey 80 


\section{Conclusions}

Indian telecommunications industry is considered as one of the success stories of liberalization and reforms that India started in 1991. From the time when the first telecom policy was announced in the year 1994, India has come a long way in making telecom services available to its citizens. The policy maker (DoT) and the Regulator (TRAI) have taken various initiatives to drive Indian government's vision and mission for telecommunications. Making services affordable and creating user awareness about telecom services are the two fundamental objectives of DoT and TRAI respectively. This study intended to found out whether the initiatives of DoT and TRAI have met their objectives of making telecom services affordable and increased the awareness of telecom services among Indian users. Review of literature revealed lack of studies in the context of user's assessment of affordability of telecom services in India. The study fills this gap up to some extent. The results of analysis of collected data (descriptive statistics and linear regression) help in an objective assessment of the achievement of affordability objective by DoT and awareness objective by TRAI.

Survey respondents in this research were educated (more than $98 \%$ were graduates), predominantly male ( $>81 \%$ ) and in the age group of $36-45$ (more than half of them). More than $90 \%$ of the respondents work in some industry in India. Hence, respondents with this profile are expected to understand the content of the questionnaire and can be considered representative of the population authors wished to study. The survey results on the first dimension i.e. awareness about telecommunications industry indicated that half of the survey respondents are aware of the policy maker DoT. Awareness about TRAI is higher, as $67 \%$ of the respondents indicated high or very high level of awareness. More than 2/3rd of respondents indicated high or very high level of awareness about Indian government's vision about telecom services. Similar numbers of surveyed respondents are aware of telecom operator's obligation of reporting their performance to government agencies.

The level of awareness about DoT and TRAI varied between the male and female respondents. The level of awareness about functions of these organizations also varied between male and female respondents. The level of awareness was found to be low in female respondents compared to male respondents. Irrespective of this difference, the awareness level about Indian Government's vision was not different between the male and female respondents. In other words, there may be difference in the level of awareness about organization, but there is no difference at gender level in awareness level about final objective of government for telecom. Different age groups are equally aware of DoT and TRAI, government's vision on telecom. Similarly, 
there is no difference in awareness level among various age groups about the telecom operator's obligation to report performance to TRAI. The awareness level was not found to vary across respondents with different education level. This was true for awareness about the organizations (TRAI and DoT) and awareness about government's vision of telecom services. Occupation seems to impact the level of awareness about DoT. However, awareness about TRAI, government's vision on telecom, and telecom operator's obligation to report performance to TRAI did not vary according to occupation of the respondents. In summary, the awareness efforts that TRAI or DoT has taken, needs to be further strengthened. With only half of respondents being aware of DoT, this represents an area of concern, considering that DoT is playing a prominent role since the early years of telecom reforms. TRAl's consumer outreach program seems to make a difference, as more people are aware about it compared to DoT. Awareness about telecom is prerequisite for users to make the most of available services and benefits from policy and regulatory initiatives.

Research finding that $85.8 \%$ of users find telecom services affordable represents an encouraging statistic for both DoT and TRAI. It may not be surprise since India has one of the lowest telecom ARPU in the world. In spite of this, if $15 \%$ of the respondents found telecom services less affordable, it calls for further study and actions to achieve the objective of affordability. The difference in affordability across gender (male and female), between different age groups and between different education levels is another important finding. The gender related variances are a definite area of action as this defeats the policy maker's vision of telecom for all.

The regression analysis between Affordability assessment and awareness indicated that awareness level impacted users' verdict on Affordability of telecom services. The regression analysis, however, indicated a very high level of variability in the model, which impacted the predictability of affordability by the awareness factors. More variable related to awareness and affordability may reduce this variability and increase the level of predictability of the model. With low predictability, it can be concluded to a certain extent, that if awareness levels are increased, it is possible that users' improved awareness level is based on finding better service options linking to their level of affordability.

In summary, TRAl's customer oriented programs seem to be making impact on the awareness level of telecom users. DoT, on the other hand, needs to make additional effort to increase its visibility among the end users of telecom services. This is also important as awareness level influences the user's assessment of the affordability of telecom services. The present study indicates that bulk of the users in India may find telecom services affordable but equal access of telecom for all need further actions from policy makers and regulators. The fact that female users find telecom services to be less 
affordable than male users represents an area of concern. Increasing awareness about telecom services among females and promotional programs targeting female population are some of the recommendations.

\section{Appendix A. Scatter Plots}

Figure 1. Scatter plot between affordability verdict and policy awareness

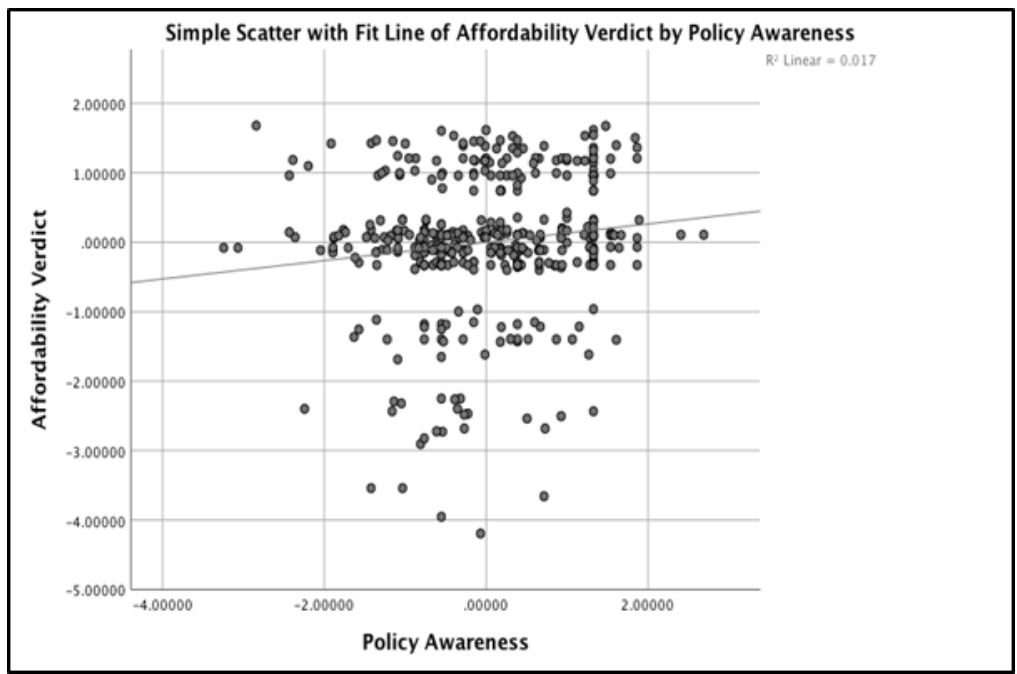

Figure 2. Scatter plot between affordability verdict and vision awareness

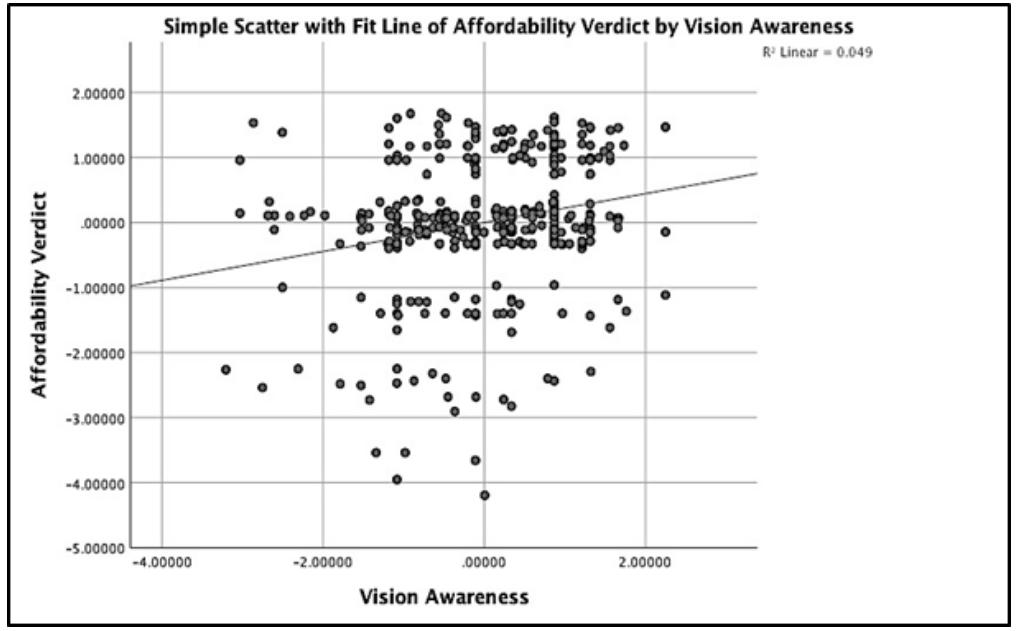

Industrija, Vol.48, No.3, 2020 


\section{References}

Abu, S. T. (2014). Competition and Innovation in Telecom Sector: Empirical Evidence from OECD Countries. Informatica Economică, 18(1/2014).

Akkaya, D. T., Ayşe Akyol, A., \& Şimşek, G. G. (2017). The effect of consumer perceptions on their attitude, behavior and purchase intention in social media advertising. Marmara Üniversitesi İktisadi ve Idari Bilimler Dergisi, 39 (II), 361388. doi: $10.14780 /$ muiibd.384073

Anderson, J. (1973). Demographic Factors Affecting Health Services Utilization: A Causal Model. Medical Care, 11(2), 104-120. Retrieved from www.jstor. org/stable/3762477

Andrés, L., Cuberes, D., \& Diouf, M.A. (2008). The Diffusion of Internet: A Cross-Country Analysis (The World Bank, MPRA Paper No. 8433).

Bomsel, O., Cave, M., Blanc, G. L., \& Neumann, K.H. (2003). How mobile termination charges shape the dynamics of the telecom sector (Final report, CERNA, University of Warwick). Retrieved from http://citeseerx.ist.psu.edu/viewdoc/ download doi=10.1.1.202.1438\&rep=rep1\&type $=$ pdf

Barboni, G., Field, E., Pande, R., Rigol, N., Schaner, S., \& Moore, C. T. (2018). A Tough Call: Understanding barriers to and impacts of women's mobile phone adoption in India. Available at https://epod.cid.harvard.edu/sites/default/files/2018-10/A\%20T ough\%20Call.pdf.

Bouckaert, J., Dijk, T., \& Verboven, F. (2010). Access regulation, competition, and broadband penetration: An international study. Telecommunications Policy, 34(11), 661-671. doi: 10.1016/j.telpol.2010.09.001

BQ (2019). Q1 Results: Bharti Airtel's Biggest Loss Since Listing Masks Business Recovery. Available at https://www.bloombergquint.com/quarterly-earnings/q1results-bharti-airtel-slips-into-loss-even-as-arpu-continues-to-rise

Chan, L. L., \& Idris, N. (2017). Validity and Reliability of the Instrument Using Exploratory Factor Analysis and Cronbach's alpha. International Journal of Academic Research in Business and Social Sciences, 7(10), 400-410.

Chinedu, C. (2008). Environmental education awareness of attitudes of secondary school students in Owerri Education Zone, Imo state. Unpublished M. ED. Thesis of the Department of Science Education, UNN.

Cochran, W.G. (1977). Sampling Techniques. New York: John Wiley and Sons.

CUTS (2016). (2016). IIT Delhi, Mobile Internet Services in India: Quality of Service, CUTS, Jaipur. Available at http://www.iitd.ac.in/research/IITD/1615_QoS_ Report_CUTS IIT.pdf

David, D. (2015). Affordability of utilizes services: extent, practice and policy. Centre on Regulation in Europe, Research Paper 1: Affordability Metrics.

Dretske, F. (2006). Perception without awareness. In Tamar Szabo Gendler \& John Hawthorne (Eds.), Perceptual experience (pp. 147-180). Oxford: Clarendon Press. 
ET (2019). BSNL FY19 loss at over Rs 14,000 crore: Govt. Available at https://economictimes.indiatimes.com/markets/stocks/earnings/bsnl-fy19-loss-atover-rs-14000-crore-govt/articleshow/70059516.cms

ET (2018). TRAl pulls up Airtel, Vodafone-Idea on minimum recharge plans. Available at https://economictimes.indiatimes.com/industry/telecom/telecom-news/traifrowns-at-telcos-threatening-to-snap-services-despite-sufficient-pre-paidbalance/articleshow/66848480.cms?from =mdr

Fankhauser, S., \& Tepic. S. (2005). Can poor consumers pay for energy and water? An affordability analysis for transition countries. Working paper No. 92 . European Bank for Reconstruction and Development.

Friendly, M., \& Denis, D. (2005). The Early Origins and Development of the Scatterplot. Journal of the history of the behavioral sciences, 41(2), 103-130. doi: 10.1002/jhbs.20078

Gan, Q., \& Hill, R. J. (2008). Measuring Housing Affordability: Looking Beyond the Median. School of Economics Discussion Paper: 2008/09. School of Economics Australian School of Business UNSW Sydney NSW 2052 Australia.

Gruber, H., \& Koutroumpis, P. (2012). Competition enhancing regulation and diffusion of innovation: the case of broadband networks. Journal of Regulatory Economics, 43(2), 168-195. https://doi.org/10.1007/s11149-012-9205-4

GSMA (2018). Connected Women: The Mobile Gender Gap Report 2018. Available at https://www.gsma.com/mobilefordevelopment/wp-content/uploads/ 2018/ 04/ GSMA_The_Mobile_Gender_Gap_Report_2018_32pp_WEBv7.pdf

Grace-Martin, K. (2012). Can a Regression Model with a Small R-squared Be Useful? The Analysis Factor. Available at http://www.theanalysisfactor.com/small-rsquared/

Hassan, A. O. (2011). Telecommunications Reform and Effects of Competition on Availability, Quality and Cost of Services in Nigeria. Public Policy and Administration Research, 1(3).

Hou, C., \& Phusit, W. (2014). The Relationship Among Brand Awareness, Brand Image, Perceived Quality, Brand Trust, Brand Loyalty and Brand Equity of Customer In China's Antivirus Software Industry. University of the Thai Chamber of Commerce, Thailand.

Hughes, M. \& Fernandez-Duque, D. (2010). Knowledge influences perception: Evidence from the Ebbinghaus illusion. Journal of Vision, 10(7), 954-954a. doi: 10.1167/10.7.954.

Irvin. R. (1985). Perception and knowledge. Acta Psychologica, 59(1), 3-22. doi: 10.1016/0001-6918(85)90039-3

Itaoka, K. (2012). Regression and interpretation low R-squared! Social Research Network 3nd Meeting Noosa. Retrieved from https://ieaghg.org/docs/General _Docs/3rd_SRN/Kenshi_Itaoka_RegressionInterpretationSECURED.pdf

ITU (2002). Competition policy in telecommunications. International Telecommunication Union workshop on competition policy in telecommunications Document: CPT/04 18 November 2002, Geneva, 20 - 22 November 2002

ITU (2015). Security in Telecommunications and Information Technology Security in Telecommunications and Information Technology: An overview of issues and the deployment of existing ITU-T Recommendations for secure Telecommunications. 
ITU (2018b). ITU Workshop on Telecommunications Service Quality Regulatory Frameworks and Experience-Driven Networking. Geneva, Switzerland. Available at https://www.itu.int/en/ITU-T/Workshops-and-Seminars/qos/201811/Docum ents/S1P1-prado-report.pdf.

ITU (2018c). Global ICT Reglatory Outlook 2018. ITU Publications, Geneva.

ITU (2018a). ICT Regulatory Tracker. Available at https://www.itu.int/net4/itu$\mathrm{d} /$ irt/\#/tracker-by-country/regulatory-tracker/2018

Jaina, P., \& Sridhar, V. (2003). Analysis of Competition and Market Structure of Basic Telecommunication Services in India. Communications \& Strategies, 52(4), 271.

Jones \& Suh (2000) as quoted in Ojo \& Olu. (2010). The Relationship Between Service Quality and Customer Satisfaction in the Telecommunication Industry: Evidence from Nigeria. BRAND: Broad Research in Accounting, Negotiation, and Distribution.

Kar, S., \& Gupta, M.P. (2017). Telecommunications Infrastructure: Using Statistical Analysis to Identify Significant Factors and to Design Policies for Indian Smart Cities. International Journal of Engineering Technology Science and Research, 4(8).

Katz. R, L. (2009). The Economic and Social Impact of Telecommunications Output: A Theoretical Framework and Empirical Evidence for Spain. Intereconomics. doi: $10.1007 / \mathrm{s} 10272-009-0276-0$

Khan, D. (2019). Airtel scraps low-valued postpaid plans to improve ARPU, boost profitability. Available at https://telecom.economictimes.indiatimes.com/news/ airtel-discontinues-low-value-postpaid-plans-to-boost-profitability/69307995

Kunigami. A, M., \& Sabater. J, V. (2010). Options to Increase Access to Telecommunications Services in Rural and Low-Income Areas. World Bank working paper no. 178.

LI, W., \& XU, L.C. (2004). The impact of privatization and competition in the telecommunications sector around the world. Journal of Law and Economics, XLVII, doi: 0022-2186/2004/4702-000X\$01.50.

Market Pulse (2011). A market pulse research report on up west July - September, 2011. Available at https://main.trai.gov.in/sites/default/files/UPW\% 20Survey\% 20Report\%20jul\%20sep\%20\%202011.pdf

Melody, W. H. (1999). Telecom reform: progress and prospects. Telecommunications Policy, 23(1), 7-34. doi.org/10.1016/S0308-5961(98)00073-1

Milne, C. (2006). Telecoms demand: measures for improving demand in developing countries - a toolkit for action. Virginia: George Mason University; 2006. Main Report (World Dialogue on Regulation).

Mohamad, A.B., Evi, D.O., \& Nur, A.B. (2018). A review on sample size determination for Cronbach's alpha test: a simple guide for researchers. Malays J Med Sci. 2018, 25(6), 85-99. doi: 10.21315/mjms2018.25.6.9

Moore, D. S., Notz, W. I, \& Flinger, M. A. (2013). The basic practice of statistics $\left(6^{\text {th }}\right.$ ed.). New York, NY: W. H. Freeman and Company

Niëns, L.M., \& Brouwer, W.B.F. (2012). Measuring the affordability of medicines: Importance and challenges. Health Policy, 112(2013), 45-52. doi: 10.1016/j.healthpol.2013.05.018.)

Noam, E. M. (2010). Regulation 3.0 for Telecom3.0. Telecommunications Policy, 34 (12), 4-10. doi: 10.1016/j.telpol.2009.11.004. 
OECD (2008). Enhancing competition in telecommunications: protecting and empowering consumers. Ministerial Background Report.

Onukogu. S. C., Ugwuanyi P. N. \& Adiaha M. S. (2018). Level of awareness, perception and attitude of senior secondary school students towards water in Chanchanga Local Government Area, Niger state. World Scientific News, 105 (2018), 74-98.

PTI (2019). MTNL Q3 standalone loss widens to Rs 832 crore, total expense rises. Available at https://www.business-standard.com/article/pti-stories/mtnl-s-decquarter-loss-widens-to-rs-832-26-cr-119021401216_1.html

Rathee (2018). Women Constitute Only $17.4 \%$ of Mobile Subscribers in India: DoT Data. Available at https://thewire.in/tech/women-mobile-subscriptions-india-department -of-telecom

Reisinger, H. (1997). The impact of research designs on $\mathrm{R} 2$ in linear regression models: an exploratory meta-analysis. Journal of Empirical Generalisations in Marketing Science, 2.

Roller, L.H., \& Waverman. L. (2001). Telecommunications infrastructure and economic development: A simultaneous approach. American. Economic Review, 91(4), 909923.

Santos, J.R.A. (1999). Cronbach's Alpha: A Tool for Assessing the Reliability of Scales. Journal of Extension, 37(2).

Sarraute, C., Blanc, P., \& Burroni, J. (2014). A Study of Age and Gender seen through Mobile Phone Usage Patterns in Mexico. doi: 10.1109/ASONAM.2014.6921683.

SG Analtics (2016). Why customers may dump a telecom operator for a new one. Available at https://www.sganalytics.com/blog/telecom-customer-survey-2016/

Sillice, M.A., Dunsiger, S., Jennings, E., Lantini, R., \& Bock, B.C. (2018). Differences in mobile phone affinity between demographic groups: implications for mobile phone delivered interventions and programs. mHealth, 4(39). doi: 10.21037/mhealth. 2018.09.06.

Symeou, P.C., \& Pollitt, M.G. (2007). Telecommunications in small economies: the impact of liberalization and alternative technologies on universal service. Working Paper Series 19/2007, Judge Business School.

Tandon, S. (2019). Airtel, Vodafone Idea focus on high revenue customers. Available at https://www.financialexpress.com/industry/airtel-vodafone-idea-focus-on-higherarpu-customers/1626585/

Telecommunication Regulation Handbook (2011). Telecommunications Regulation Handbook Tenth Anniversary Edition. The International Bank for Reconstruction and Development / The World Bank, InfoDev, and The International Telecommunication Union.

Taherdost, H., Sahibuddin, S., \& Jalaiyoon, N. (2014). Exploratory Factor Analysis; Concepts and Theory, Advances in Applied and Pure Mathematics, 375-382.

TheWire (2018). Women Constitute Only 17.4\% of Mobile Subscribers in India: DoT Data. Available at https://thewire.in/tech/women-mobile-subscriptions-indiadepartment-of-telecom

Thillairajan, A., Mahalingam, A., \& Deep, A. (2013). Impact of private-sector involvement on access and quality of service in electricity, telecom, and water supply sectors: a systematic review of the evidence in developing countries. London: EPPICentre, Social Science Research Unit, Institute of Education, University of London.

Industrija, Vol.48, No.3, 2020 
TRAI (2010). Quality of Service Assessment Report of survey for Basic (Wireline), Cellular Mobile (Wireless) \& Broadband Services for Andhra Pradesh Circle. Available at https://main.trai.gov.in/sites/default/files/APSurvey_2010_ JAN_ MAR.pdf

TRAI (2017). A Twenty Year Odyssey 1997-2017.

TRAI (2018). TRAl conducts 'Consumer Outreach Programme (COP)' on 03.08.2018 at Noida (UP). Information Note to the Press [Press Release No. 8'1/2018. Available at https://main.trai.gov.in/sites/default/files/PRNo8907082018.pdf

TRAI (2019). Highlights of Telecom Subscription Data as on $31^{\text {st }}$ May 2019. Available at https://trai.gov.in/sites/default/files/PR_No.49of2019.pdf

TUV (2006). Report on quality of service \& customer satisfaction survey (Quarter July 2006 to Sep. 2006). Available at https://main.trai.gov.in/sites/default/files/ TUVreport.pdf

Wagstaff, A., \& Van Doorslaer E (2001). Paying for health care: quantifying fairness, catastrophe, and impoverishment, with applications to Vietnam, 1993-98. Washington: The World Bank.

Wagstaff, A., \& Van Doorslaer E. (2003). Catastrophe and impoverishment in paying for health care: with applications to Vietnam 1993-1998. Health Economics, 12, 92134.

Wallsten, S. J. (1999). An Empirical Analysis of Competition, Privatization, and Regulation in Telecommunications Markets in Africa and Latin America (World Bank Policy Research Working Paper No. 2136). Retrieved from https://ssrn.com/abstract $=614956$

Walsh, A. (2015). Impact of Demographics on Healthcare Utilization. Online Journal of Public Health Informatics, 7(1), e57, Available at https://www.ncbi.nlm.nih.gov/ pmc/articles/PMC4512389/)

Watson, B. R., Zamith, R., Cavanah, S., \& Lewis, S.C. (2015). Are Demographics Adequate Controls for Cell-Phone-Only Coverage Bias in Mass Communication Research? Journalism \& Mass Communication Quarterly, 92(3), 723-743. doi: $10.1177 / 1077699015589187$ 